\title{
Hepatotoxicity and biochemical evaluation of a novel breakfast food produced from the blend of fonio (Digitaria iburua Stapf) and pigeon pea (Cajanus cajan (L.) Millspaugh) in albino rats
}

\author{
Grace O. Babarinde ${ }^{1 *}\left(\mathbb{D}\right.$, Akos A. Ebun ${ }^{1}$ and Peter I. Adegbola ${ }^{2}$
}

\begin{abstract}
Background: The production of novel foods from underutilized nutritious tropical crops is increasing; however, the toxicological studies are sparse. In this study, the safety of the breakfast food produced from the blend of fonio and pigeon pea was examined by evaluating the biochemical and toxicological parameters of the breakfast food using Wistar albino rats. Twenty male Wistar albino rats subdivided into 4 groups of 5 were separately fed with four food samples (100\% fonio, 80:20 fonio:pigeon pea, standard rat feed (control) and a commercial brand of corn flake) for 28 days after which the animals were sacrificed and blood samples collected for analyses. Body weight, blood glucose, biochemical, and hematological parameters were examined during the experimental period.

Results: The feeding of rats with the four diets did not cause mortality and adverse toxicity during the experimental period. Steady body weight gain was observed in fonio-pigeon pea fed rats, and slight changes were obtained in percentage blood glucose. There was no significant difference in the levels of white blood cells, lymphocytes, mean corpuscular volume, platelet, high-density lipoprotein, catalase, SOD, and malondialdehyde of the group fed with fonio-pigeon pea diet as compared with the control group. Furthermore, significant $(p<0.05)$ lower levels of density lipoprotein, triacylglyceride, and cholesterol were observed in the fonio-pigeon pea-fed rats than the control group. The liver function marker of fonio-pigeon pea-fed-rat and the control showed no significant difference.

Conclusion: The study showed no severe toxicity in the test animals, although a mild loss of liver parenchyma and variation in size and shape of nuclei were observed in the group fed with the fonio-pigeon pea diet.
\end{abstract}

Keywords: Breakfast food, Fonio, Pigeon pea, Toxicity, Oxidative stress

\section{Background}

Food product development is gaining increasing attention in most developing countries to meet the demand for improved nutritional status among the low-income earners and the vulnerable, which make up the teeming

\footnotetext{
* Correspondence: gobabarinde@lautech.edu.ng

'Department of Food Science, Ladoke Akintola University of Technology, Ogbomoso, Nigeria

Full list of author information is available at the end of the article
}

population. Also, the demand for dietary diversity to ensure food and nutrition security has propelled the development of novel food products from locally available food materials. The majority of these novel products are from underutilized cereals and legumes. These crops have been neglected or underutilized due to certain conditions such as hard to cook nature, high level of antinutritional factor/toxic constituents, small grain size,

\section{Springer Open}

(0) The Author(s). 2020 Open Access This article is licensed under a Creative Commons Attribution 4.0 International License, which permits use, sharing, adaptation, distribution and reproduction in any medium or format, as long as you give appropriate credit to the original author(s) and the source, provide a link to the Creative Commons licence, and indicate if changes were made. The images or other third party material in this article are included in the article's Creative Commons licence, unless indicated otherwise in a credit line to the material. If material is not included in the article's Creative Commons licence and your intended use is not permitted by statutory regulation or exceeds the permitted use, you will need to obtain permission directly from the copyright holder. To view a copy of this licence, visit http://creativecommons.org/licenses/by/4.0/. 
susceptibility to insect infestation, and difficulties in postharvest handling (Jideani and Jideani 2011).

Cereals and legumes are among the most important crops used in the development of new products such as expanded snacks, weaning foods, complementary foods, and breakfast cereals. Several scientific works had evaluated the chemical, functional, proximate, and mineral profiles of some foods developed from less-exploited cereal and legumes (Ayo et al. 2007; Ayo et al. 2010). McWatters et al. (2003) evaluated physical and sensory characteristics of cookies prepared from wheat, fonio, and cowpea flours. Cookie was also developed from a blend of pigeon pea and cocoyam by Okpala and Chinyelu (2011). The authors reported that 80:20 formulation had the highest scores for all parameters evaluated when compared with control. Adebayo-Oyetoro et al. (2019) examined the quality attributes of weaning food from sorghum co-fermented with pigeon pea where a sample with 80:20 level of substitution gave the best overall acceptability. Some researchers (Adeyanju et al. 2018; Akinwande et al. 2014; Boncompagni et al. 2019; Okpala and Okoli 2011) have also developed different food products and efforts were geared towards the assessment of the nutritional, anti-nutritional, and sensory attributes; however, there is limited information on the toxicological factors of these developed products. These authors suggested the introduction of $20 \%$ legume flour in cereal-based product to have an acceptable proteinrich food. Toxic effect is simply defined as a mild or chronic condition in the function, behavior, and structure of experimental animals when exposed to chemical substances (Ware 2001). (Olatoye and Arueya 2018) opined that before the products are launched into the market, toxicological studies through animal study should be carried out to ascertain the level of risk of such product. This is necessary since the genetic and biological characteristic of rats are in close resemblance to human and many symptoms of human conditions can be replicated in rats.

The rise in cases of hepatic porphyria, hemorrhages in various organs, and bad functioning of certain organs of individuals, especially in developed countries has increased the need to carry out toxicological studies of food products developed from under-exploited crops. Although, some investigations have established the diseases-preventive and healthful compounds in some of cereal and legume grains, due to their high fiber content and gluten-free attribute (Kahlon 2009), it is also crucial to ascertain the safety of these foods using some clinical indicators due to their toxic and anti-nutritional components.

To combat malnutrition and ensure the availability of low-cost nutritious food, novel breakfast food was developed from blends of fonio and pigeon pea. Fonio is an energy-giving crop that can contribute to the daily energy requirements. It offers about 3.6 calories per gram of fonio grain, which is similar to the value obtained in other cereals (Jideani and Jideani 2011). The cereal is easy to digest and does not sharply increase blood sugar level (Holesh and Martins 2019). This ancient grain has been traditionally used in regular food due to its nutritional and health benefits; however, its full potential as ingredients in processed food is not fully harnessed.

Jideani (1999) reported that fonio and iburu have potentials to be used as nutraceuticals due to their antioxidant, phenolic, and cholesterol-lowering properties. Its medicinal potential in the treatment of diabetic patient has been documented in some parts of West Africa and it is also important to ascertain the anti-diabetic potential of this cereal when used in combination with legumes. The healthful, cholesterol-lowering potential of the crop has also been predicted (Kasarda 2001; Kahlon 2009). Although fonio is a good source of essential amino acids (National Research Council 1996) lacking in most cereals, the protein content is not sufficient enough to meet the daily requirement, and this has led to the development of breakfast food supplemented with pigeon pea.

Pigeon pea (Cajanus cajan) is a locally grown lessexploited grain legume of sub-Sahara Africa. It is cultivated in tropical countries, which have a temperature range from 20 to $40{ }^{\circ} \mathrm{C}$ (Eltayeb et al. 2010). The grain is a relatively low-cost vegetable protein, fiber, vitamins, and mineral sources (Fasoyiro et al. 2010). Pigeon pea varieties have protein contents in the range of 18.5 and 26.3\% (Rampersad et al. 2003; Eltayeb et al. 2010; Okpala and Chinyelu 2011). The protein content is similar to what is obtainable in cowpea and groundnut majorly used in complementing food product from maize (Mbaeyi-Nwaoha and Obetta 2016; Ewuola et al. 2015; Rufina et al. 2016).

Pigeon pea adapts well to the agronomic conditions in Nigeria; however, the hard-to-cook phenomenon and the high level of anti-nutrients have limited the crop's utilization (El-Tabey Shebat 1992). Both the cereal and legume contain anti-nutritional factors whose toxicological effects are rarely studied in newly developed food products. This research, therefore, evaluated toxicological parameters of a novel food developed from a blend of fonio and pigeon pea.

\section{Methods}

\section{Samples procurement}

Fonio (Digitaria iburua), variety iburu, was procured from smallholder farmers in Jos, Plateau State, Nigeria. Pigeon pea (Cajanas cajan), variety otili pupa, was obtained from an open market in Saki, Oyo State, Nigeria. 
Production of breakfast food from fonio and pigeon pea flour blends

Breakfast food samples were prepared from two formulations, which ratio is $80: 20$ fonio to pigeon pea flour, and $100 \%$ fonio flour. The formulation, $80: 20$ fonio to pigeon pea, was used based on the fact that $20 \%$ of legume had been recommended by previous researchers as safe and acceptable by consumers when incorporating legume in a cereal-based product (Akinwande et al. 2014; Babarinde et al. 2020). Flour was thoroughly homogenized in Kenwood mixer followed by the addition of $500 \mathrm{ml}$ of water to form a thick paste. The paste was fed into a cold extruder (UNOLD Pasta Maker) for proper mixing to obtain a flake-like product. The extruded sample was baked in an oven at $280{ }^{\circ} \mathrm{C}$ for $5 \mathrm{~min}$ and a golden brown flake-like sample was obtained. A commercial brand breakfast cereal (corn flakes) was procured and served as control 1. Standard rat feed pellet (100 g maize, 25 palm kernel cake, $15 \mathrm{~g}$ full fat, $38 \mathrm{~g}$ wheat offal, bone meal $10 \mathrm{~g}, 25 \mathrm{~g}$ groundnut cake, $1.5 \mathrm{~g}$ limestone, $1.25 \mathrm{~g}$ fish meal, premix $\mathrm{B}$, and $0.5 \mathrm{~g}$ salt) was used as standard control/reference.

\section{Animal care and handling}

Male Wistar strain albino rats with weight ranging between 90 and $100 \mathrm{~g}$, and age range of 6-7 weeks were obtained from the breeding section of Department of Biochemistry, Ladoke Akintola University of Technology, Ogbomoso. There were four experimental units of five rats per unit which made 20 albino rats that were housed in metabolic cages in a climate-controlled environment with free access to food and water ad libitium and adequate facilities to collect faeces and urine. The animals were acclimatized and fed with commercialized standard rat pellet with free access to food and potable water for 1 week, after which 20 albino rats were randomly assigned into four groups with each group containing 5 rats of equal or similar weight ranging from 113.06 to 124.62 g; group 1 was fed with standard chow and served as control; group 2, 3, and 4 were fed with flakes prepared from $100 \%$ fonio, $80 \%$ fonio, and $20 \%$ pigeon pea and commercial brand corn flakes, respectively. Weight changes of the animals fed with the breakfast food, and their wellbeing were constantly monitored during the experiment using the guidelines for national and institutional protection of experimental animals (National Academies Press 2011).

\section{Food, water intake, and body weight of the rat}

The intake of food and water was monitored daily and the data pooled together on weekly basis. The experimental animals were given known weight and volume of feed and water daily, which was supplied around 8 am daily. Food consumption of the experimental animals and water consumption of all rats were measured by subtracting the leftover weights from the initial weights. The left over feed and water were quantified after $24 \mathrm{~h}$ the following morning and the feed and water intake were determined by difference.

The animals were allowed access to food and water ad libitum. The food and water intake were apportioned to each group of 5 animals; in the experiment, food and water intakes were allowed to be taken voluntarily by the experimental animals based on their needs; so the animals were not gavaged with water throughout the experiment. Weight changes were determined by the difference between the final weight and initial weight (Eq. 1 ). The body weight of the rats was monitored weekly and measured in grams using a weighing balance.

$$
\text { \%body weight change }=\frac{\text { Final weight }- \text { Initial weight }}{\text { Initial weight }} \times 100
$$

\section{Blood glucose determination}

Weekly blood glucose of rats was monitored throughout the experiment and on the last day of the experiment. Prior to the last day of the experiment, animals were fasted overnight and a sample of blood was obtained from the rat. The blood glucose was determined on an Acu-check glucometer with the acu-check glucose test strip. Glucose concentration in the blood sample was expressed in $\mathrm{mg} / \mathrm{dl}$ (ADA 2013).

\section{Determination of hematological parameters \\ Blood collection}

Consequently, upon 28 days of the experiment, the rats were fasted overnight after which chloroform was added inside a desiccator to anesthesize the animals. They were then sacrificed. For hematological analysis, blood was drained into Bijour bottles pre-filled with little dried tetra-acetic ethylenediamine acid powder as described by Oluwajuyitan (2019).

\section{Serum biochemistry}

The blood sample was collected from the rats by cardiac puncture after overnight fasting at the end of 28 days of the experiment. The blood sample was placed in nonEDTA test tubes. The serum obtained was centrifuged at $4000 \mathrm{rpm}$ for $10 \mathrm{~min}$ and utilized to determine the total cholesterol, total triglyceride, high-density lipoprotein (HDL), and low-density lipoprotein (LDL). Total cholesterol was determined by enzymatic analysis (Seide et al. 1983) using the Randox Commercial kit.

\section{Procedure for hematological parameters}

To determine the hematological parameters, a hematology Analyzer (Model SYSMEX KX $21 \mathrm{~N}$ ) was used. The blood sample was collected in bottles containing $50 \mu \mathrm{l}$ 
anticoagulant (EDTA) and diluted with Cell Park in a counting chamber. The instrument measured all the hematological parameters required automatically. The hematological parameters determined were white blood cell (WBC), red blood cell (RBC), hemoglobin (HGB), parked cell volume (PCV), lymphocytes (LYM), mean corpuscular volume (MCV), and platelet (PLT).

\section{Histological examination}

Histological examination was carried out by the method described by Palipoch and Punsawad (2013). The liver was initially placed in a $10 \%$ solution of neutral buffered formalin for $24 \mathrm{~h}$ and later washed with $70 \%$ ethanol. It was then placed in small beakers stirred in a magnetic stirrer and dehydrated in ascending grade of alcohol (70-100\%). After it was embedded in paraffin, the paraffin blocks were sectioned using an ultra-microtome, placed on glass slides, and dried overnight. Slides were later stained with hematoxylin and eosin dyes and then examined under a light microscope.

\section{Statistical analysis}

Data obtained in this study were expressed as mean \pm $\mathrm{SE}$ and were analyzed by one-way analysis of variance (ANOVA) while the significant differences between means were identified by Duncan multiple range test at $p<0.05$ using Statistical Package for Social Science (SPSS 21.0)

\section{Results}

\section{Food and water intake of rats fed with breakfast feed}

The result in Table 1 showed the food and water intake of rat fed with breakfast meals. The results of animals fed with 100\% fonio, 80:20 fonio-pigeon pea, and corn flakes showed a steady increase in food intake from week 1 to 4 with accompanying increase in water intake, but no consistent pattern was observed for animals fed on the standard feed. The feeding of rats with the four diets did not cause mortality and adverse toxicity during the experimental period.

\section{Effect of the breakfast feed on the weight of rats}

The weight changes of animals fed with the four diets with time are presented in Table 2. Steady weight gains were observed in all groups to varying degrees throughout the study period. At the end of 4 weeks, the group fed with commercial corn flakes had the least weight gain $(7.39 \%)$ which is significantly lower than others.

\section{Change in blood glucose level of rats fed with the breakfast food}

The results of percentage blood glucose of rats fed with standard feed and blend of fonio-pigeon pea showed a steady increase in all tested rats (Table 3). Significant ( $p$ $<0.05$ ) difference was observed in the percentage change in blood glucose in rats across the groups with the highest percentage in the standard control group, followed by commercial corn flakes, $100 \%$ fonio, and 80:20 formulated diet at week 1 and 4, respectively. The lowest percentage change in blood glucose was observed in the group fed with fonio and 80:20 fonio-pigeon pea diet.

\section{Effects of the breakfast food on the hematological parameters in rat}

The results of the hematological indices of rats fed with $100 \%$ fonio, 80:20 fonio-pigeon pea diet, corn flakes, and standard rat feed are shown in Table 4. It was observed that WBC count was highest in the commercial corn flakes $\left(15.82 \times 10^{9} / \mathrm{L}\right)$. Similarly, the commercial corn flakes had the highest platelet $\left(907.00 \times 10^{3} \mu \mathrm{L}\right)$ with no significant difference in the values recorded for other groups. Concerning other hematological parameters (RBC, HGB, PCV, LYM, and MCV), the values obtained from the rats fed with fonio-pigeon pea diet were not significantly different $(p>0.05)$ from the standard control group (Table 4).

Effect of the breakfast meals on the lipid profiles of rats Results in Table 5 showed the serum lipid profiles of rats across the various groups. The values of HDL ranged from 15.40 to $25.45 \mathrm{mg} / \mathrm{dl}$ where group fed with $100 \%$ fonio diet had significantly lower levels of HDL than other groups. The values of LDL also ranged from 1.77 $\mathrm{mg} / \mathrm{dl}$ in 80:20 fonio-pigeon pea group to $6.97 \mathrm{mg} / \mathrm{dl}$ in commercial corn flakes group. Rats fed with 80:20 foniopigeon pea and $100 \%$ fonio had significantly lower LDL values than rats fed with commercial cornflakes and standard feeds (control). With respect to the cholesterol

Table 1 Food and water intake of rats fed with the composite feed and standards

\begin{tabular}{|c|c|c|c|c|c|c|c|c|}
\hline \multirow[t]{3}{*}{ Groups } & \multicolumn{3}{|c|}{ Food intake (g) } & \multicolumn{5}{|c|}{ Water intake $(\mathrm{L})$} \\
\hline & \multicolumn{8}{|c|}{ Weeks } \\
\hline & 1 & 2 & 3 & 4 & 1 & 2 & 3 & 4 \\
\hline Standard feed & 120.32 & 116.43 & 131.64 & 114.32 & 1.95 & 1.94 & 2.01 & 2.28 \\
\hline $100 \%$ fonio & 140.67 & 205.54 & 217.78 & 508.78 & 1.96 & 2.03 & 2.19 & 2.41 \\
\hline $80: 20$ fonio-pigeon pea & 221.54 & 234.56 & 248.04 & 436.01 & 1.31 & 1.36 & 1.49 & 1.89 \\
\hline Corn flakes & 390.04 & 304.74 & 515.73 & 673.41 & 1.96 & 2.08 & 2.17 & 2.20 \\
\hline
\end{tabular}


Table 2 Percentage change in body weight of rats fed with breakfast food

\begin{tabular}{|c|c|c|c|c|}
\hline \multirow[t]{2}{*}{ Groups } & \multicolumn{4}{|c|}{ Percentage change in weight (\%) } \\
\hline & Week 1 & Week 2 & Week 3 & Week 4 \\
\hline Standard feed & $5.52 \pm 1.29^{b}$ & $8.93 \pm 1.29^{a}$ & $10.76 \pm 1.37^{\mathrm{a}}$ & $17.70 \pm 1.46^{\mathrm{a}}$ \\
\hline $100 \%$ fonio & $10.49 \pm 0.03^{\mathrm{a}}$ & $11.03 \pm 0.02^{\mathrm{a}}$ & $12.97 \pm 0.02^{\mathrm{a}}$ & $12.17 \pm 0.04^{b}$ \\
\hline 80:20 fonio-pigeon pea & $10.76 \pm 0.00^{c}$ & $10.32 \pm 1.11^{\mathrm{a}}$ & $12.80 \pm 0.00^{\mathrm{a}}$ & $17.71 \pm 0.01^{\mathrm{a}}$ \\
\hline Corn flakes & $6.36 \pm 0.00^{c}$ & $7.32 \pm 0.00^{b}$ & $6.07 \pm 0.94^{b}$ & $7.39 \pm 0.00^{c}$ \\
\hline
\end{tabular}

Values were expressed as mean \pm SEM and considered significant at $p<0.05$. Values with different superscript letters $(a, b, c)$ along the same column are significantly different

level, the group fed with 80:20 fonio-pigeon diet had the least value $(176.73 \mathrm{mg} / \mathrm{dl})$, which was significantly lower than the values obtained in the other groups. The highest level of cholesterol was observed in commercial corn flakes $(259.59 \mathrm{mg} / \mathrm{dl})$. The values of TAG varied from 103.24 to $154.97 \mathrm{mg} / \mathrm{dl}$ in 80:20 fonio-pigeon diet and commercial corn flakes, respectively. The group fed with 80:20 fonio-pigeon pea had a significantly lower content of TAG than the other samples. Rats fed with 80:20 fonio-pigeon pea had significantly lower levels of TAG when compared with other samples (Table 5).

The level of cholesterol $(176.73 \mathrm{mg} / \mathrm{dl})$ was lower in the group fed with 80:20 fonio-pigeon pea diet (Table 5) than other groups The values obtained in the group fed with 80:20 formulation were significantly lower than the standard control group but similar to the values recorded in the rats fed with $100 \%$ fonio.

\section{Effect of the breakfast food on the liver function}

The serum levels of some liver biomarkers assessed in this study are shown in Table 5. A higher significant ( $p$ $<0.05$ ) level was observed in the serum alanine aminotransferase (ALT) of rats fed with standard feed than 80 : 20 fonio-pigeon pea diet. A similar trend was observed in the aspartate aminotransferase (AST) level of rats fed with 100\% fonio and 80:20 fonio-pigeon pea diet. Gamma-glutamyl transferase (GGT) and total protein were significantly $(p<0.05)$ higher in the rats fed with standard feed (control) and 100\% fonio. The increase in the total protein of animal fed with 100\% fonio could be due to the type of amino acid in the diet. Liver enzymes are used as indicators in proper liver functioning because they are compartmentalized, and changes in the serum level can be used to evaluate disease state.

\section{Effect of the breakfast food on the antioxidant status of rats}

The antioxidant parameters of rats across the various groups showed a significant $(p<0.05)$ lower level of catalase activity of rats fed with commercial corn flakes than other groups (Table 6) No significant difference was observed in superoxide dismutase (SOD) activity across the groups. As shown in Table 6, a significant ( $p$ $<0.05$ ) higher value of malondialdehyde (MDA) was observed in rats fed with 100\% fonio while 80:20 foniopigeon pea diet-fed group had the least MDA.

\section{Effect of the breakfast food on the liver histology of rats}

The liver photomicrograph (Fig. 1) showed the portal triad (PT) composed of the hepatic vein (HV) and artery (HA) as well as the bile duct (BD). The well-distributed hepatocytes $(\mathrm{H})$ across the general cytoarchitecture are demonstrated across the study groups. Results from the micrographs showed a plate of hepatic cells from $100 \%$ fonio and 80:20 fonio-pigeon pea diet groups are characterized by a mild loss of liver parenchyma and some mild derangement in the cellular profiles. Also, images from this treatment showed a plate of hepatic cells, some mild loss of liver parenchyma, disorganization, and dilation of the central vein. There were also variations in the sizes and shapes of the nuclei. Standard and commercial corn flakes groups showed no altered panoramic morphological presentation accompanied by well outlined cellular profile. Hepatocytes sheets were radially

Table 3 Percentage change in glucose of rats fed with breakfast food

\begin{tabular}{|c|c|c|c|c|}
\hline \multirow[t]{2}{*}{ Groups } & \multicolumn{4}{|c|}{ Percentage glucose (\%) } \\
\hline & Week 1 & Week 2 & Week 3 & Week 4 \\
\hline Standard feed & $17.91 \pm 0.04^{\mathrm{a}}$ & $26.03 \pm 0.01^{b}$ & $44.99 \pm 0.06^{\mathrm{a}}$ & $54.11 \pm 1.34^{\mathrm{a}}$ \\
\hline 100:0 fonio & $8.36 \pm 0.01^{c}$ & $7.69 \pm 0.02^{c}$ & $6.03 \pm 0.47^{d}$ & $17.54 \pm 0.01^{c}$ \\
\hline 80:20 fonio-pigeon pea & $3.12 \pm 0.01^{d}$ & $7.53 \pm 0.28^{c}$ & $12.68 \pm 0.01^{c}$ & $17.55 \pm 0.03^{c}$ \\
\hline Corn flakes & $15.61 \pm 0.01^{b}$ & $39.91 \pm 0.07^{a}$ & $40.53 \pm 0.00^{b}$ & $25.92 \pm 0.02^{b}$ \\
\hline
\end{tabular}

Values were expressed as mean \pm SEM and considered significant at $p<0.05$. Values with different superscript letters (a, b, c) along the same column are significantly different 
Table 4 Hematological parameters of rats fed with breakfast food

\begin{tabular}{|c|c|c|c|c|c|c|c|}
\hline \multirow[t]{2}{*}{ Groups } & \multicolumn{7}{|c|}{ Hematological parameters } \\
\hline & $\overline{W B C}\left(10^{9} / L\right)$ & $\operatorname{RBC}\left(10^{12} / L\right)$ & $\mathrm{HGB}(\mathrm{g} / \mathrm{dl})$ & PCV (\%) & $\operatorname{LYM}\left(10^{3} / \mu \mathrm{L}\right)$ & $\mathrm{MCV}\left(10^{-15} / \mathrm{L}\right)$ & $\operatorname{PLT}\left(10^{3} / \mu \mathrm{L}\right)$ \\
\hline Standard feed & $11.08 \pm 0.70^{\mathrm{a}}$ & $7.10 \pm 0.10^{b}$ & $9.96 \pm 0.17^{b}$ & $38.44 \pm 1.53^{b}$ & $80.52 \pm 1.77^{\mathrm{a}}$ & $54.08 \pm 1.42^{\mathrm{a}}$ & $510.25 \pm 23.19^{a}$ \\
\hline Fonio & $8.45 \pm 0.94^{\mathrm{a}}$ & $7.12 \pm 0.27^{b}$ & $9.84 \pm 0.59^{a, b}$ & $37.44 \pm 1.02^{\mathrm{ab}}$ & $73.36 \pm 3.10^{a}$ & $52.66 \pm 0.92^{\mathrm{a}}$ & $536.00 \pm 36.43^{a}$ \\
\hline 80:20 F-P & $9.72 \pm 0.51^{a}$ & $6.28 \pm 0.28^{\mathrm{a}}$ & $8.74 \pm 0.38^{\mathrm{a}}$ & $34.14 \pm 1.23^{\mathrm{a}}$ & $81.80 \pm 3.50^{a}$ & $54.64 \pm 2.35^{\mathrm{a}}$ & $546.25 \pm 71.83^{\mathrm{a}}$ \\
\hline Corn flakes & $15.82 \pm 2.56^{\mathrm{b}}$ & $7.39 \pm 0.14^{b}$ & $10.46 \pm 0.22^{b}$ & $39.34 \pm 1.52^{b}$ & $74.04 \pm 4.86^{\mathrm{a}}$ & $53.28 \pm 1.96^{\mathrm{a}}$ & $907.00 \pm 82.33^{b}$ \\
\hline
\end{tabular}

Values were expressed as mean \pm SEM and considered significant at $p<0.05$. Values with different superscript letters along the same column are significantly different

WBC white blood cell, RBC red blood cell, HGB hemoglobin, PCV parked cell volume, LYM lymphocytes, MCV mean corpuscular volume, $P L T$ platelet $F-P$ fonio pigeon pea

arranged and the nuclei well demarcated. The intervening sinusoids, normal central vein, and hepatic artery features were in line with normal histology.

\section{Discussion}

The animals fed well on both the standard feed and the developed breakfast food. The increased intake of $100 \%$ fonio, 80:20 fonio-pigeon pea, and corn flakes could be due to familiarity with the feed over time and the palatability of the food. Factors affecting lower intake of water include dry matter content or the physical form of the diets. Therefore, lower intake of water by the experimental animal fed with 80:20 fonio-pigeon pea could be due to the physical form of the formulated diet, which was harder than corn flakes and standard feed.

The higher weight gain (17.71\%) recorded for 80:20 formulation on day 20 could be attributed to the addition of pigeon pea in the diet, which supplied more protein than corn flakes sample and $100 \%$ fonio sample. Ayo et al. (2010) reported pigeon pea had protein contents ranging from 23 to $26 \%$ protein. The nutritional composition of the experimental diet has been reported in our recent study (Babarinde et al. 2020) which indicated blend of fonio and pigeon pea is rich in energy (363.09 kcal), protein (24.85\%), fat (1.20), ash (1.03\%), and crude fiber (1.18). This could have also contributed to the weight gain of the group fed with fonio-pigeon pea diet. Foods and nutrients are very essential for the proper functioning and growth of the body.
Fonio is a cereal that is consumed by some diabetic patients because of its ability to lower blood sugar (Jideani and Jideani 2011). The lowest percentage blood glucose recorded in rats fed with fonio-pigeon pea diet could be due to high-crude fiber in the blends of fonio and pigeon pea (Babarinde et al. 2020). Increase in blood glucose level higher than $160 \mathrm{mg} / \mathrm{dl}$ is commonly used as an indication of diabetes mellitus in experimental studies (Stanley and Venugopal 2001). Alleviation of malnutrition with associated health problems such as diabetes, obesity, neurodegenerative, and cardiovascular diseases have been observed when cereals and legumes were used as nutraceuticals in human nutrition (Erukainure et al. 2013). The lower blood glucose observed in the current study showed the diet might have a low to moderate glycemic index. According to the American Diabetic Association (2004), the glycemic response to food is influenced by factors such as fiber content, processing, individual tolerances, and other foods included in the meal. Studies have shown that legumes are rich in fiber and could play significant roles in lowering blood sugar (Kaczmarczyk et al. 2012). Therefore, supplementation with pigeon pea as observed in this study might contribute to a reduction in blood glucose.

WBC of the group fed with the developed diet (80:20 fonio to pigeon pea) was significantly $(p<0.05)$ lower than the rats fed with standard and cornflakes diets. Amudha and Vanitha (2019) reported that blood parameters are used in evaluating the response of the body to damage or stress. The estimation of the complete blood

Table 5 Serum lipid profile of rats fed with breakfast food

\begin{tabular}{|c|c|c|c|c|c|c|c|c|}
\hline \multirow[t]{2}{*}{ Groups } & \multicolumn{4}{|l|}{ Lipid profile } & \multicolumn{4}{|l|}{ Liver marker } \\
\hline & $\mathrm{HDL}(\mathrm{mg} / \mathrm{dl})$ & LDL (mg/dl) & TAG (mg/dl) & $\begin{array}{l}\text { Cholesterol } \\
(\mathrm{mg} / \mathrm{dl})\end{array}$ & $\mathrm{ALT}(\mathrm{U} / \mathrm{L})$ & AST (U/L) & GGT(U/L) & $\begin{array}{l}\text { Total protein } \\
(\mathrm{g} / \mathrm{dl})\end{array}$ \\
\hline Standard feed & $15.70 \pm 0.77^{b}$ & $4.21 \pm 0.49^{b}$ & $134.09 \pm 13.3^{b}$ & $229.21 \pm 11^{\mathrm{b}}$ & $76.99 \pm 7.99^{b}$ & $129.35 \pm 44.82^{a}$ & $24.16 \pm 5.46^{\mathrm{a}}$ & $8.05 \pm 0.47^{b}$ \\
\hline 100\% fonio & $15.40 \pm 0.22^{b}$ & 1.21. $\pm 0.15^{c}$ & $127.06 \pm 8.28^{c}$ & $186.96 \pm 11.81^{c}$ & $34.63 \pm 9.77^{a}$ & $287.78 \pm 37.92^{b}$ & $17.26 \pm 1.99^{\mathrm{a}}$ & $8.90 \pm 0.24^{b}$ \\
\hline 80:20 FPP & $18.86 \pm 1.68^{b}$ & $1.77 \pm 00.70^{c}$ & $103.24 \pm 8.05^{d}$ & $176.73 \pm 13.31^{c}$ & $67.57 \pm 5.89^{b}$ & $431.31 \pm 53.36^{c}$ & $36.24 \pm 8.63^{\mathrm{ab}}$ & $7.69 \pm 0.11^{b}$ \\
\hline Corn flakes & $25.45 \pm 4.41^{\mathrm{a}}$ & $6.97 \pm 0.00^{\mathrm{a}}$ & $154.97 \pm 4.02^{a}$ & $259.59 \pm 5.02^{\mathrm{a}}$ & $36.38 \pm 3.14^{a}$ & $114.46 \pm 14.90^{\mathrm{a}}$ & $61.17 \pm 10.65^{b}$ & $6.66 \pm 0.12^{\mathrm{a}}$ \\
\hline
\end{tabular}

Values were expressed as mean \pm SEM and considered significant at $p<0.05$. Values with different superscript letters along the same column are significantly different HDL high-density lipoprotein, LDL low-density lipoprotein, TAG triacylglyceride, ALT alanine aminotransferase, AST aspartate aminotransferase, GGT Gammaglutamyl transferase 
Table 6 Antioxidant parameters of rats fed with breakfast food

\begin{tabular}{llll}
\hline Groups & Antioxidant parameters & & \\
\cline { 2 - 4 } & Catalase $(\mathrm{u} / \mathrm{ml} / \mathrm{min})$ & SOD $(\mathrm{u} / \mathrm{ml})$ & $\mathrm{MDA}(\mu \mathrm{M})$ \\
\hline Standard feed & $32.06 \pm 2.03^{\mathrm{b}}$ & $1.89 \pm 0.42^{\mathrm{ab}}$ & $2.98 \pm 0.77^{\mathrm{a}}$ \\
$100 \%$ fonio & $34.51 \pm 0.13^{\mathrm{b}}$ & $2.48 \pm 0.43^{\mathrm{b}}$ & $6.00 \pm 1.12^{\mathrm{b}}$ \\
$80: 20$ fonio-pigeon pea & $32.60 \pm 1.25^{\mathrm{b}}$ & $1.93 \pm 0.02^{\mathrm{ab}}$ & $2.21 \pm 0.71^{\mathrm{a}}$ \\
Corn flakes & $16.96 \pm 0.30^{\mathrm{a}}$ & $1.14 \pm 0.26^{\mathrm{a}}$ & $4.45 \pm 0 . .^{35 \mathrm{ab}}$ \\
\hline
\end{tabular}

Values were expressed as mean \pm SEM and considered significant at $p<0.05$. Values with different superscript letters along the same column are significantly different

count gives extensive information on the hematological status in disease condition (Lathia and Joshi 2004). For instance, the white blood cell is involved in the body's immune system and fights against infection (Mojisola et al. 2013). While the presence of white blood cells (WBC) may indicate a level of immunity, relatively high WBC counts may have implications for disease conditions (Aletor and Egberongbe 1992; Oluwole et al. 2015). It, therefore, implies that the developed food did not pose any threat pathologically.

A significant $(p<0.05)$ higher difference was observed in the packed cell volume (PCV), haemoglobin (HGB) concentration, and red blood cell (RBC) count of the group fed with standard control diet than the foniopigeon pea. The lowest value observed in hematology parameters, especially PCV, hemoglobin and the red blood cell count could be due to the presence of anti- nutrients in the pigeon pea diet. Okafor et al. (2018) reported maize-pigeon $(60: 40)$ pea contained phytate (446.84 mg/100 g), an anti-nutrient with the ability to chelate minerals. Phytate can form insoluble complexes with iron $(\mathrm{Fe})$, thereby limiting its bioavailability in the human body. The reduced level of PCV, hemoglobin, and red blood cell could be attributed to the presence of phytate in the fonio-pigeon pea. Low bioavailability of iron can lead to anemic condition (Vikas and Sinha 2018). When processing underutilized legumes for use as food or food ingredients, it is important to ensure the anti-nutrients are reduced to a safe level.

In this study, rats fed with fonio-pigeon pea diet had significantly higher HDL level when compared with the standard control. Previous studies have related increased HDL with decreased cardiovascular risk (Chien et al. 2007). The protective function of HDL against vascular-
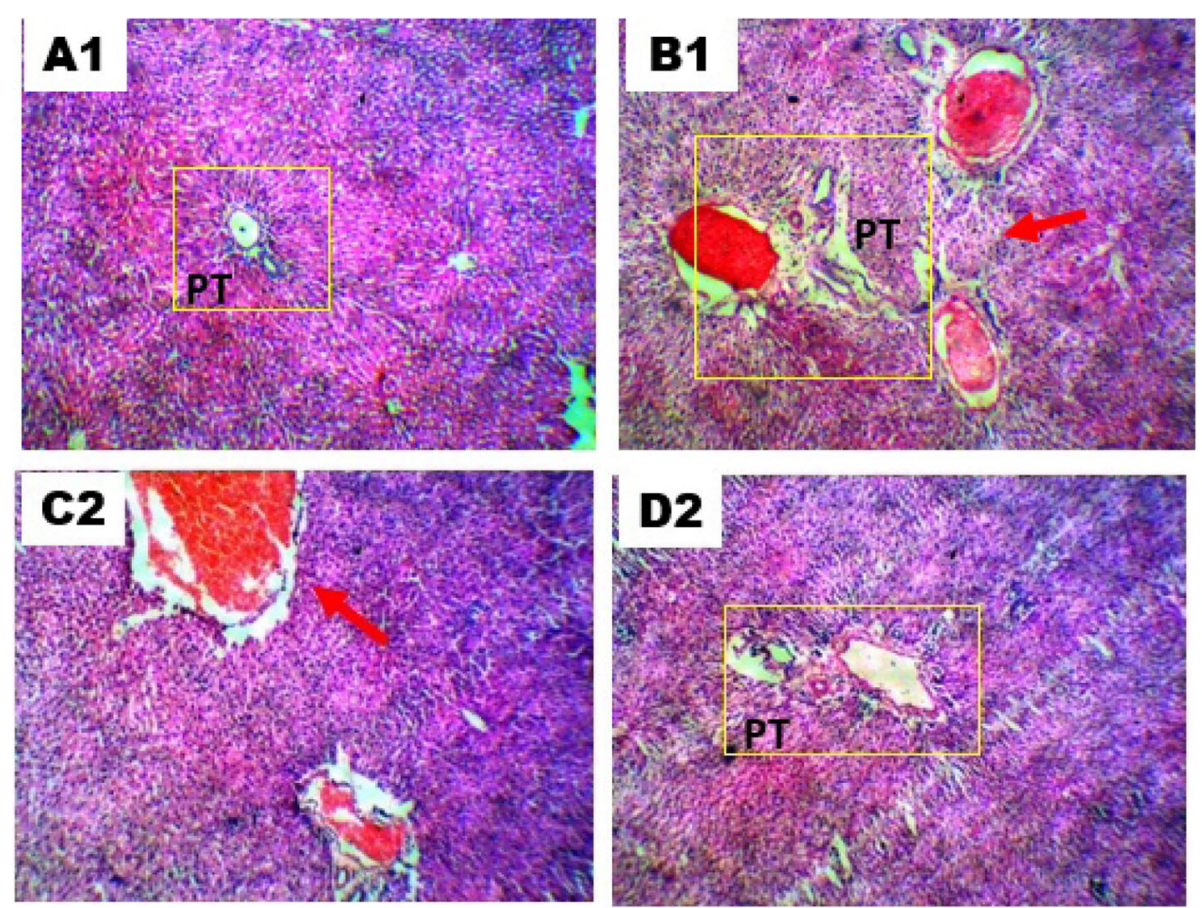

Fig. 1 Photomicrographs of liver sections stained with hematoxylin and eosin. A1 Rats fed with standard feed. B1 Rats fed 100\% fonio. C2 Rats fed with 80:20 fonio-pigeon pea. D2 Rats fed with corn flakes 
related disease comes from its involvement in the reverse transport of cholesterol (Navab et al. 2005). This lipoprotein transport cholesterol from the peripheral tissues to the liver, where it is converted to bile acid. In other words, it is involved in cholesterol excretion. The relatively low values of LDL observed in groups fed with $100 \%$ fonio and $80: 20$ fonio-pigeon pea diets stressed the importance of utilization of less exploited crops in food product development. Previous studies recognized amino acids, especially the sulphur-containing amino acids to be the most effective in modulating lipid metabolism. These amino acids have potentials in increasing HDL and decreasing LDL (Bieżanowska-Kopeć and Leszczyńska 2017). In this study, some vital amino acids which include methionine and cysteine might have contributed to the lowering effects of LDL in the foniopigeon group. Babarinde et al. (2020) reported the presence of sulphur-containing-amino acids in different ratios of fonio and pigeon pea blend. Low-density lipoprotein is the lipoprotein that carries cholesterol to the body tissues (Bieżanowska-Kopeć and Leszczyńska 2017). In oxidative stress, LDL could induce a parade of inflammatory processes with consequent formation of plagues in the arterial wall, which may eventually result in arteriosclerosis (Liu et al. 2008; Adegbola et al. 2017).

The value of TAG in rats fed with 80:20 formulations was significantly $(p<0.05)$ lower than the standard control feed. The rise in the level of triglyceride is mainly associated with increase free fatty acid mobilization from peripheral deports as well as increased lipolysis (lipid breakdown) (Murray et al. 2000; Garg et al. 2010). TAG's role, especially in health matters, depends on the associated carbon chain. The saturated ones are usually of concern in diabetic conditions where lipid replaces glucose as the main source of energy due to the defect in glucose metabolism (Nelson and Cox 2000). The developed diet did not raise the blood cholesterol of the rats. Adegbola et al. (2017) gave an extensive review of the contribution of cholesterol to the etiology of cardiovascular diseases. Cholesterol could disrupt vascular structure and function, consequently causing plagues, occlusion, lesions, and reduction in curing ischemia/reperfusion injury. The higher, therefore, the cholesterol levels, the higher the risk of cardiovascular issues.

Lower levels of cholesterol observed in fonio, and 80:20 fonio-pigeon pea-fed rats agreed with the report of Kahlon (2009) who reported the cholesterol-lowering potential of fonio grain. The liver is the main site of serum protein synthesis and changes in their level is commonly used as an indicator of liver function and malnutrition (Mizuno et al. 1996; Oluwole et al. 2015). No changes were observed in the serum total protein level of the rats in this research. Hence, the developed breakfast food can be said to be non-toxic to hepatocytes. Amudha and Vanitha
(2019) reported that a decrease in serum protein and albumin ethanolic extract of $E$. acoroides is non-toxic to hepatocytes.

Oluwole et al. (2015) had reported how increased levels of ALT, AST, and ALP have been linked with hepatic tissue dysfunction and damage. The results here suggested that feeding of animals with the composite feed does not induce severe liver damage. High level of AST observed in 80:20 fonio-pigeon pea diet could be due to the presence of some anti-nutritional factors in the formulation, and this further explains the importance of a toxicological study in newly developed food products. Changes in ALT, AST, and ALP enzyme levels could be linked to damage in cells (Kashaw and Nema 2011).

In oxidative stress, the antioxidant parameters become overwhelmed because of increased free-radical production and decrease in antioxidant enzyme levels, which consequently result in the oxidation of important biomolecules (Puddu et al. 2009). Oxidative stress was linked with the development of degenerative diseases (Lobo et al. 2010). Determination of changes in the major biomarkers of oxidative stress and their accumulations can be used in the assessment of antioxidant status in vivo (Saliu and Bawa-Allah 2012).

SOD aids the dismutation of highly reactive superoxides to produce oxygen and hydrogen peroxide while catalase protects the cells by preventing $\mathrm{H}_{2} \mathrm{O}_{2}$ from further breaking down to a more reactive $\mathrm{OH}$ radical (Matés et al. 1999). The result obtained shows that breakfast food can maintain the normal antioxidant status since levels obtained are not significantly different from the control. During oxidative stress, the chain of lipid peroxidation reactions can be initiated with resulting damage to the membrane and associated cell death. MDA is a byproduct of lipid peroxidation, and its level in serum can be used to determine the extent of oxidative damage to the membrane (Oluwole et al. 2015). In this study, however, the MDA level in the group fed with fonio-pigeon pea diet was not significantly $(p>0.05)$ different from the standard control. Higher MDA observed in the group fed with $100 \%$ fonio could be attributed to the presence of anti-nutritional factors such as tannin and phytate (Jideani 1999). Wang et al. (2019) reported a significant increase in the MDA level when the effects of tannic acid on porcine enterocytes were investigated.

Slight changes were observed in the liver histology which is indicative of liver toxicity or injury. Yahaya et al. (2019) reported that some plant substances can damage the liver since the organ is the primary target of toxins because all substances ingested are processed in the liver. Changes observed in the liver tissues of the rats fed with fonio-pigeon pea as shown in Fig. 1 might be due to the presence of some toxic/anti-nutritional components in the developed diet. Emire et al. (2013) 
reported deaths after consumption of certain types of legumes are increasing despite cooking. The authors also reported the increasing rate of renal and liver diseases. It, therefore, becomes necessary to ensure adequate processing of foods before consumption.

\section{Conclusion}

This study showed that the production of breakfast food from the blend of 80:20 fonio-pigeon pea had no significant toxicity on the serum markers. Increase in weight of rat fed with $100 \%$ fonio and 80:20 fonio to pigeon pea indicated the diet can promote growth. Development of breakfast food from the blend of 80:20 fonio-pigeon pea did not cause mortality and severe toxic conditions in the test animals. However, the consumption of the food resulted in mild histological effects which raise concerns for safety especially in long-term exposure. Therefore, the evaluation of toxicological parameters of newly developed food products with improved nutritional composition before consumption is recommended.

\section{Abbreviations}

WBC: White blood cell; RBC: Red blood cell; HGB: Hemoglobin; PCV: Parked cell volume; LYM: Lymphocytes; MCV: Mean corpuscular volume; PLT: Platelet; LDL: Low-density lipoprotein; HDL: High-density lipoprotein; SOD: Superoxide dismutase

\section{Acknowledgements}

The authors acknowledged Professor A. A. Adegbola, the former Director of Academic Planning, Ladoke Akintola University of Technology, Ogbomoso, Nigeria, for the roles he played in securing the grant for this research.

\section{Authors' contributions}

The author GOB conceptualized and designed the research, developed the manuscript, and interpreted part of the results. AAE prepared the breakfast food and executed the toxicological and biochemical analysis. API assisted in procuring the rats, executed the euthanasia of the animals, interpreted parts of the result, and carried out statistical analysis. All the authors have read and approved the final manuscript.

\section{Funding}

This work was supported by the Federal Government of Nigeria under the scheme of the Tertiary Educational Trust Fund (TETFund) Institution-based Research Grant, Ladoke Akintola University of Technology, Ogbomoso, Nigeria (LAUTECH 2017). The funding body provided funds for the design, laboratory experiments, analysis, and interpretation of data but did not play authorship role.

\section{Availability of data and materials}

All generated data are analyzed and included in this published article.

\section{Ethics approval and consent to participate}

The handling of the experimental animals was carried out in line with the experimental protocol of the University for the use of animals in the laboratory experiments and following the guidance provided by National Research Council of the National Academies Press (2011).

\section{Consent for publication}

Not applicable

\section{Competing interests}

No conflict of interest was declared by the authors of this research. The funding body provided funds for the research. All authors played significant roles in data collection, analysis, and writing of the final report.

\section{Author details}

${ }^{1}$ Department of Food Science, Ladoke Akintola University of Technology,

Ogbomoso, Nigeria. ${ }^{2}$ Department of Biochemistry, Ladoke Akintola University of Technology, Ogbomoso, Nigeria.

Received: 4 June 2020 Accepted: 25 August 2020

Published online: 14 September 2020

\section{References}

ADA (2013) American Diabetes Association: standard of medical care in diabetes. Diabetes Care 36(1):S11-S66

Adebayo-Oyetoro AO, Adeyeye SAO, Olatidoye OP, Ogundipe OO, Adenekan OE (2019) Effect of co-fermentation on the quality attributes of weaning food produced from sorghum (Sorghum bicolor) and pigeon pea (Cajanus cajan). J Culinary Sci Tech 17(2):118-135

Adegbola P, Ifewumi A, Wasiu H, Tolulope O (2017) Antioxidant and antiinflammatory medicinal plants have potential role in the treatment of cardiovascular disease: a review. Am J Cardio Dis 7(2):19-32

Adeyanju JA, Babarinde GO, Adekunle AA, Olajire SO, Adegboye AA (2018) Quality characteristics of cookies produced from wheat, acha and pigeon pea flour blends. Annals Food Sci Tech 19(4):691-698

Akinwande BA, Babarinde GO, Ajeigbe OP (2014) Production and evaluation of ready to eat breakfast cereals from blends of whole maize and African yam bean (Sphenostylis stenocarpa). Elixir Food Sci 72:25625-25628

Aletor VA, Egberongbe O (1992) Feeding differently processed soya bean part 2. An assessment of haematological responses in the chicken. Mol Nutr Food Res J 36(4):364-369

American Diabetic Association (2004) Nutrition principles and recommendations in diabetes. Diabetes Care 27:S36-\$46

Amudha P, Vanitha V (2019) Toxicological, biochemical and histopathological evaluation of the ethanolic extract of seagrass-Enhalus acoroides in albino wistar rats. Biocatal Agric Biotechnol 18:101082

Ayo JA, Ayo VA, Nkama I, Adewori R (2007) Physicochemical, in-vitro digestibility and organoleptic evaluation of fonio wheat biscuit supplemented with soybean flour. Nigerian Food J 25(1):77-89

Ayo JA, Ikuomola DS, Sanni TA, Esan YO, Ayo VA, Ajayi G (2010) Evaluation of nutritional quality of soybean-fonio composite biscuits. Nigerian Food J 28(2): $132-138$

Babarinde GO, Adeyanju JA, Ogunleye KY, Ebun AA, Wadele D (2020) Nutritional composition of gluten-free flour from blend of fonio (Digitaria iburua) and pigeon pea (Cajanus cajan) and its suitability for breakfast food. J Food Sci Technol. https://doi.org/10.1007/s13197-020-04393-7

Bieżanowska-Kopeć R, Leszczyńska T (2017) Effect of high methionine and folic acid dieton the level of homocysteine and lipid profile in experimental rats. Polish J Food Nutr Sci 3(67):219-224

Boncompagni E, Nielsen E, Sanogo MD, Coghetto V, Temporiti ME, Daglia M, DiLorenzo A, Doria E (2019) Anti-nutritional metabolites in six traditional Africans cereals. J Food Nutr Res 58(2):115-124

Chien KL, Hsu HC, Sung FC, Su TC, Chen MF, Lee YT (2007) Metabolic syndrome as a risk factor for coronary heart disease and stroke: an 11-year prospective cohort in Taiwan community. Atherosclerosis 194:214-221

El-Tabey Shebat AM (1992) Hard-to-cook phenomenon in legumes. Food Rev Int 8:191-221

Eltayeb ARSM, Ali AO, Haran R (2010) The chemical composition of pigeon pea (Cajanus cajan) seeds and functional properties of protein isolate. Pak J Nutr 9:1069-1073

Emire SA, Jha YK, Mekam F (2013) Role of anti-nutritional factors in food industry beverage. Food World 2:23-28

Erukainure OL, Ebuehi OA, Adeboyejo FO, Aliyu MC, Elemo GN (2013) Hematological and biochemical changes in diabetic rats fed with fiberenriched cake. J Acute Med 3:39-44

Ewuola GO, Ibironke SI, Fashakin JB (2015) Formulation and nutritional evaluation of maize, bambara groundnut and cowpea seeds blends complementary food. AJFN 4:101-105

Fasoyiro SB, Akande SR, Arowora KA, Sodeko OO, Sulaiman PO, Olapade CO, Odir CE (2010) Physico-chemical and sensory properties of pigeon pea (Cajanus cajan L) flour. Afr J Food Sci 4:120-126

Garg M, Garg C, Dhar VJ, Kalia AN (2010) Standardized alcoholic extract of phyllanthus fraternus exerts potential action against disturbed biochemical parameters in diabetic rats. Afr J Biochem Res 4:186-190 
Holesh JE, Martins A (2019) Physiology, Carbohydrates. StatPearls Publishing LLC, National Center for Biotechnology Information, Bethesda MD, USA

Jideani IA (1999) Traditional and possible technological uses of Digitaria exilis (acha) and Digitaria iburua (iburu): a review. Plant Foods Hum Nutr 54:363-374

Jideani IA, Jideani VA (2011) Developments on the cereal grains Digitaria exilis (fonio) and Digitaria iburu (iburu). J Food Sci Tech 48(3):251-259

Kaczmarczyk M, Miller MJ, Freund GS (2012) The health benefits of dietary fibre: beyond the usual suspects of type 2 diabetes mellitus, cardiovascular disease and colon cancer. Metab. 61(8):1058-1068

Kahlon TS (2009) Evaluating healthful properties of cereals and cereal fractions by their bile-acid-binding potential. Cereal Foods World 54:118-121

Kasarda DD (2001) Grains in relation to celiac disease. Cereal Foods World 46: 209-210

Kashaw V, Nema A, Agarwal A (2011) Hepatoprotective prospective of herbal drugs and their vesicular carriers-a review. Int J Res Pharmaceut Biomed Sci 2:360-374

Lathia TB, Joshi R (2004) Can hematological parameters discriminate malaria from non malarious acute febrile illness in the tropics? India J Med Sci 58(6):239244

Liu HY, Qui NX, Ding HH, Yao RQ (2008) Polyphenols contents and antioxidant capacity of 68 chinese herbals suitable for medical or food uses. Food Res Int 41:363-370

Lobo V, Patil A, Phatak A, Chandra N (2010) Free radicals, antioxidants and functional foods: impact on human health. Pharmacol Rev 4(8):118-126

Matés JM, Pérez-Gómez C, deCastro IN (1999) Antioxidant enzymes and human diseases. Clin Biochem 32:595-603

Mbaeyi-Nwaoha IE, Obetta FC (2016) Production and evaluation of nutrientdense complementary food from millet (Pennisetum glaucum), pigeon pea (Cajanus cajan) and seedless breadfruit (Artocarpus altillis) leaf powder blends. African J Food Sci 10(9):143-156

McWatters KH, Ouedraogo JB, Resurreccion AVA, Hung Y, Phillips RD (2003) Physical and sensory characteristics of sugar cookies containing mixtures of wheat, fonio (Digitaria exilis) and cowpea (Vigna unguiculata) flours. Int J Food Sci Tech 38(4):403-410

Mizuno A, Uematsu T, Gotoh S, Katoh E, Nakashima M (1996) The measurement of caffeine concentration in scalp hair as an indicator of liver function. J Pharm Pharmacol 48:660-664

Mojisola CCA, Akhere MA, Omonkhua O (2013) Effects of anogeissus leiocarpuson haematological parameters of mice infected with plasmodium berghei. J Plant Studies 2(2):13-21

Murray RK, Granner DK, Mayes PA, Rowell WW (2000) Harpers biochemistry, 25th edn. Appleton and Lange, Stanford, pp 610-617

National Academies Press (2011) Guide for the care and use of laboratory animals, 8th edn. The National Academies Press, Washington DC. https://doi. org/10.17226/12910

National Research Council (1996) 'Fonio (Acha)'. Lost crops of Africa: volume I: grains. Lost crops of Africa 1. National Academies Press, Washington DC

Navab M, Ananthramaiah GM, Reddy ST, VanLenten BJ, Ansell BJ, Fonarow GC, Vahabzadeh K, Hama S, Hough G, Kamranpour N, Berliner JA, Lusis AJ, Fogelman AM (2005) The oxidation hypothesis of atherogenesis: the role of oxidized phospholipids and HDL. J Lipid Res 45:993-1007

Nelson DL, Cox MM (2000) Lehninger, principle of biochemistry, 3rd edn. Worth Publishing, New York

Okafor UI, Omemu AM, Obadina AO, Bankole MO, Adeyeye SAO (2018) Nutritional composition and antinutritional properties of maize ogi cofermented with pigeon pea. Food Sci Nutr 6(2):424-439

Okpala LC, Chinyelu VA (2011) Physicochemical, nutritional and organoleptic evaluation of cookies from pigeon pea (Cajanus cajan) and cocoyam (Xanthosoma sp) flour blends. AFJAND 11(6):5431-5443

Okpala LC, Okoli EC (2011) Nutritional evaluation of cookies produced from pigeon pea, cocoyam and sorghum flour blends. Afr J Biotechnol 10(3): 433-438

Olatoye KK, Arueya GL (2018) Toxicological parameters of albino rats fed with extruded snacks from aerial yam (Dioscoria bulbifera) and African breadfruit seed (Treculia africana). Food Sci Nutr 6:94-100

Oluwajuyitan TD (2019) Nutritional qualities and diabetic potentials of dough meal from plantain (Musa ABB), tiger nut (Cyperus esculentus) and soy bean (Glycine max) flour using rat model M.Tech. Thesis, Federal University of Technology Akure Nigeria

Oluwole OB, Elemo GN, Kosoko SB, Adeyoju A, Oyegbami F, Owolabi SO, Taiwo LT, Olasehinde TA, Akinwale TE (2015) Nutritional properties and toxicological assessment of high nutrient biscuit developed from blends of some cereals and legumes. J Nutr Dis Theory 5(4):1-5

Palipoch S, Punsawad C (2013) Biochemical and histological study of rat, liver and kidney injury induced by cisplatin. J Toxic Pat 26(3):293-299

Puddu P, Puddu GM, Cravero E, Pascalis S, Muscari A (2009) The emerging role of cardiovascular risk factor-induced mitochondrial dysfunction in atherogenesis. J Biomed Sci 16:1-9

Rampersad R, Badreie N, Comissiong E (2003) Physico-chemical and sensory characteristics of flavored snacks from extruded cassava /pigeon pea flour. J Food Sci 68:363-367

Rufina NB, Ayogu N, Nnam M (2016) Evaluation of two local cowpea species for nutrient, anti nutrient, and phytochemical compositions and organoleptic attributes of their wheat based cookies. Food Nutr Res J 60:29600

Saliu JK, Bawa-Allah KA (2012) Toxicological effects of lead and zinc on the antioxidant enzyme activities of post juvenile clarias gariepinus. Res Env 2:21-26

Seide J, Hagele EO, Ziegenhorn J, Wahlefed A (1983) Reagent for the determination of serum total cholesterol with improved lipolytic efficiency. Clin Chem 29:1075-1080

Stanley AMP, Venugopal MP (2001) Anti-oxidant action of tinospora cordifolia root extract in alloxan diabetic rats. Phytother Res 15:213-218

Vikas K, Sinha Amit K (2018) General aspects of phytases. In: Nunes CS, Kumar V (eds) Enzymes in human and animal nutrition, p 590, Academic Press, Massachusetts, USA. https://doi.org/10.1016/C20150-04258-7

Wang J, Xiao H, Zhu Y, Liu S, Yuan Z, Wu J, Wen L (2019) Tannic acid induces the mitochondrial pathway of apoptosis and $s$ phase arrest in porcine intestinal IPEC-J2 cells. Toxins 11(7):397

Ware GW (2001) Reviews of environmental contamination and toxicology. Springer Verlag, Heidelberg

Yahaya T, Shehu K, Isah H, Oladele E, Shemisere U (2019) Toxicological evaluation of the leaves of Guiera senegalensis (J.F. Gme), Cassia occidentalis (Linn), and Ziziphus mauritiana (lam). Beni-Suef Univ J Basic Appl Sci 8:14. https://doi. org/10.1186/s43088-019-0015-y

\section{Publisher's Note}

Springer Nature remains neutral with regard to jurisdictional claims in published maps and institutional affiliations.

\section{Submit your manuscript to a SpringerOpen ${ }^{\circ}$ journal and benefit from:}

- Convenient online submission

- Rigorous peer review

- Open access: articles freely available online

High visibility within the field

- Retaining the copyright to your article

Submit your next manuscript at $>$ springeropen.com 